\title{
QUASI-PUBLIC REAL ESTATE WITHIN THE CITY OF WROCŁAW
}

\author{
Maria Hełdak, assoc. prof., PhD. \\ Department of Spatial Economy \\ University of Environmental and Life Sciences in Wroctaw \\ e-mail:maria.heldak@up.wroc.pl
}

Agnieszka Stacherzak, M.Sc.

Department of Spatial Economy

University of Environmental and Life Sciences in Wroctaw

e-mail: agnieszka.stacherzak@up.wroc.pl

\section{Zofia Więckowicz, prof., PhD.}

Department of Spatial Economy

University of Environmental and Life Sciences in Wroctaw

e-mail: zofia.więckowicz@up.wroc.pl

\begin{abstract}
The study undertakes the subject of public shopping centers in Wrocław as representative of quasipublic space. Public space should enable public discussion, whereas the public events organized in malls have little to do with public debate. The users of shopping centers are usually consumers or business entities whose main goal is to improve the quality of their lives.

Public space should be available without any additional permission to use it. It should also be freely accessible and provide the opportunity for various people to congregate-this is seen as a positive feature of space that is worth visiting. Public space should also promote the notion of public property and encourage its users to express and exchange opinions. Contemporary malls serve as an attempt at providing a replacement for public space.

The study aims to represent the scale of shopping centers operating within the space of the city of Wrocław, the area they occupy and the economic consequences they entail for small entrepreneurs operating in the region where they exist.
\end{abstract}

Key words: public space, quasi-public real estate, shopping centers.

JEL Classification: L81, M30.

Citation: Hełdak M., Stacherzak A., Więckowicz Z., 2015, Quasi-Public Real Estate Within the City of Wroctaw, Real Estate Management and Valuation, Vol. 23, No. 1, pp. 75-83.

DOI: $10.1515 /$ remav-2015-0007

\section{Introduction}

Within countries utilizing the free market economic model, property is distinguished as public and private. The need to introduce such a division stems mostly from the difference in goals pursued by means of these two types of property - and not in order to privilege any particular type of ownership (HABDAS 2012). In Poland, private and public subjects are represented first and foremost by the State Treasury and local government units. When deliberating the issue with regard to roles public space is to serve, one might decide that such a solution is more beneficial for the functioning of a property and the execution of its respective functions. 
There are three basic advantages associated with public property that have been recognized and distinguished between in literature (LEHAVI 2008):

- positive external effects (externalities) resulting from open public space, involving the possibility to use it for social and recreational purposes, which might lead to an increase in the value of the real estate located in its vicinity,

- promoting the idea of egalitarianism and stimulating members of society to interact with one another, which increases their familiarity with and understanding of different values and customs - this is considered fundamental for all social groups,

- the possibility of using public property for the purpose of public debate, exchanging opinions including political opinions-fundraising for various aims, organizing social actions and hosting cultural meetings.

Instances of the above-mentioned events can also be found in shopping centers, yet some may argue that they have little to do with public debate. Shopping mall users are comprised of consumers and business entities whose main goal is to improve the quality of their lives.

The aim of this study is to represent the scale of shopping malls operating within the space of the city of Wrocław. The research examines the area they occupy and the economic consequences they entail to small entrepreneurs operating in the region where these centers exist.

The authors analyze the retail development market using data collected from the following sources: the Central Statistical Office, Cushman \& Wakefield, Invest in Wrocław, the Wrocław Agglomeration Development Agency, as well as supplementary personal observations. The analysis was performed over the last three years. A SWOT analysis performed by students as part of a course in real estate brokerage was used to evaluate the influence of malls on the environment.

\section{Public space characteristics}

Public space is defined in the Act on Spatial Planning and Development of March 27, 2003 (consolidated text, 2012 Journal Of Laws, item 647 as amended) as an area of special importance for the fulfillment of the needs of citizens, the improvement of the quality of their lives, and one which fosters the forming of social relations due to its location and functional-spatial characteristics formulated in the Study of Determinants and Directions for Spatial Development of a given gmina (municipality).

Public space should be available without any additional permission to use it. One trait of such space is also free access and the opportunity for various people to congregate-this is seen as a positive feature of space that is worth visiting. Public space should promote public property and the opportunity to express and exchange opinions. Many observers claim that public space should be accessible to everyone, co-created by everyone and serve values which are considered worthy and accepted within a given society (PALICKI 2009).

The conscious organization and maintenance of public space is an indispensable element of the process of revitalizing and managing space. Public sidewalks, streets and walkways often serve as an initial incentive encouraging the development or improvement of real estate located in their vicinity. This phenomenon is undoubtedly a positive aspect of the proper management of space (POLKO 2006).

The growth of gigantic commercial-residential or purely residential centers did not bring about the creation of user-friendly public space. As a result, examples of space which fulfils only some of the above-mentioned characteristics exist, as opposed to public space in its traditional sense.

Moreover, space is being increasingly dominated by consumption (GLENNIE 1998). The competitive market economy has brought about new tasks for merchandisers and altered the attitudes and behaviors of potential clients. This was followed by the rapid growth of the retail development market (CELKA 2012).The role of privately-owned real estate intended for public use-where the space is "sanitized" and the people who use it are separated from subjects whose presence is unwanted, while all interactions and social identities are subject to stimulation (sanitize, separate, stimulate) - is increasing (COLLINS, BLOMLEY, 2003). Shopping centers, which are the subject of the research, and retail buildings and shopping arcades are an example of such space. A number of terms, such as quasi-public space (TYNDALL 2010) or private-public space (VOYCE 2006), are recognized due to the ambiguous nature of shopping centers.

The constant growth tendency of this type of space with regard to area leads to a decrease in the role of streets and squares as the basis for city life-a phenomenon noted since the beginning of the $20^{\text {th }}$ century (MICIUKIEWICZ 2006). Shopping centers in the United States are usually located on the 
outskirts, which led to the depopulation and degradation of downtown areas of numerous American cities, especially in the 1970s (JACKSON 1996). To this day, shopping districts that stretch along city streets often perish in favor of malls and shopping arcades. Sealed off store spaces with no attractive displays have a negative impact on the image of the city.

\section{The retail development market as quasi-public space in Wrocław}

The secondary real estate market is a set of conditions for the transfer of rights to real estate which already had a former owner. Contracts are made within these conditions to create mutual rights and responsibilities, connected with real estate holding (KUCHARSKA - STASIAK 2006). Real estate is purchased on the secondary market from a former purchaser. The secondary retail development market involves the purchase/sale, but most of all, the renting of retail space.

Wrocław is home to a very well-developed market of contemporary retail facilities. The current total supply amounts to $640,000 \mathrm{~m}^{2}$, including 15 shopping and shopping/entertainment centers $(68 \%$ of the total leased area), 4 shopping parks (18\%), 7 freestanding retail warehouses (13\%) and 1 outlet center (LASALLE 2012) (Fig. 1).

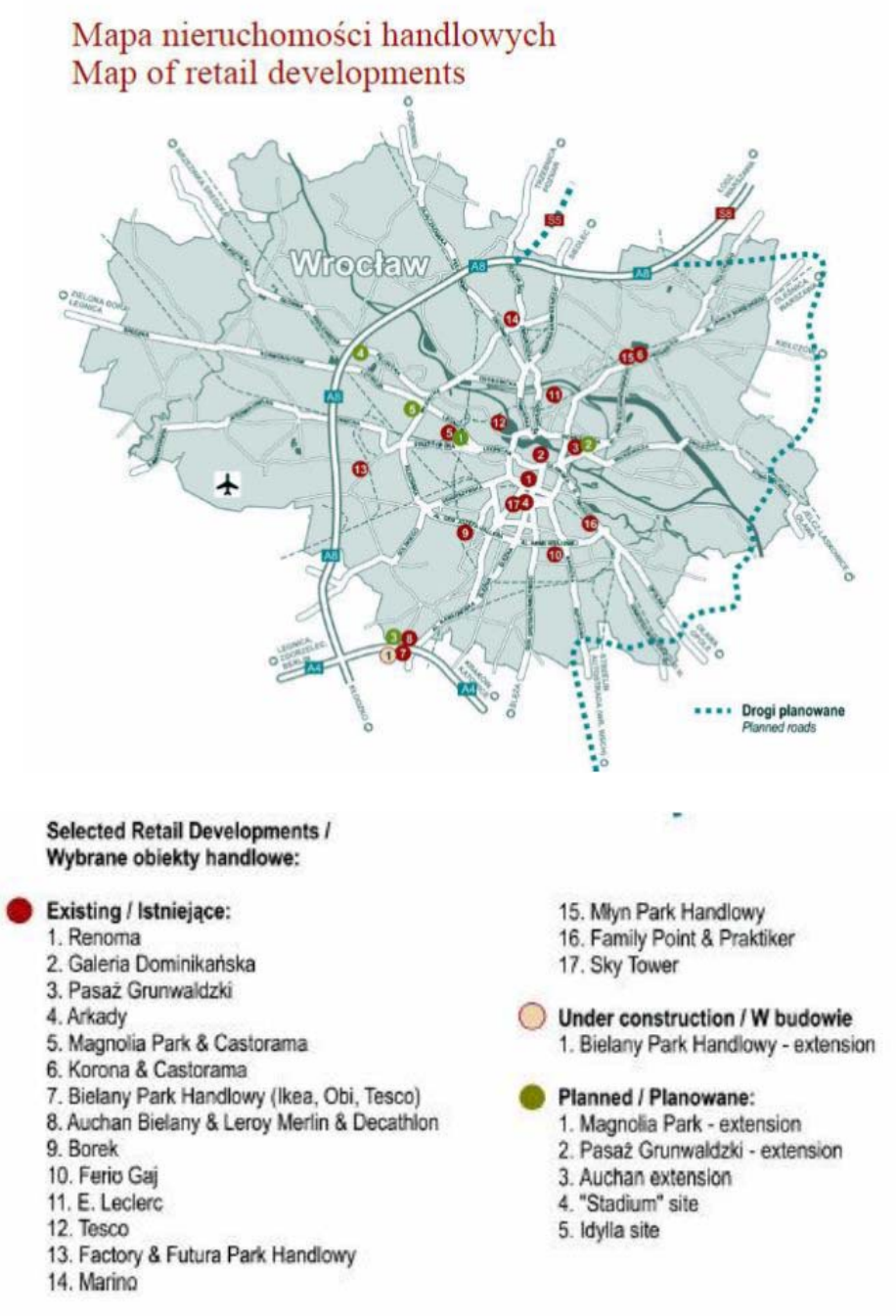

Fig. 1. Map of retail developments in Wrocław. Source: LaSalle (2012).

The 434,000 $\mathrm{m}^{2}$ supply of areas for lease in Wrocław is, along with Pozań, the highest among the eight main agglomerations in Poland when examined in terms of the saturation indicator measured in $\mathrm{m}^{2}$ of area for lease per 1000 residents.

The level of maturity of a given market is expressed by an important indicator showing the relation between the size of the market, the purchasing power of local residents and the level of retail area 
saturation in $\mathrm{m}^{2}$ per 1,000 residents. By analyzing the chart below (Fig. 2) one can notice that the following large agglomerations: Wrocław, Poznań, Tricity (Trójmiasto), Szczecin and Cracow, as well as smaller cities: Płock, Zielona Góra, Zgorzelec and Lubin offer the largest possibilities for development.

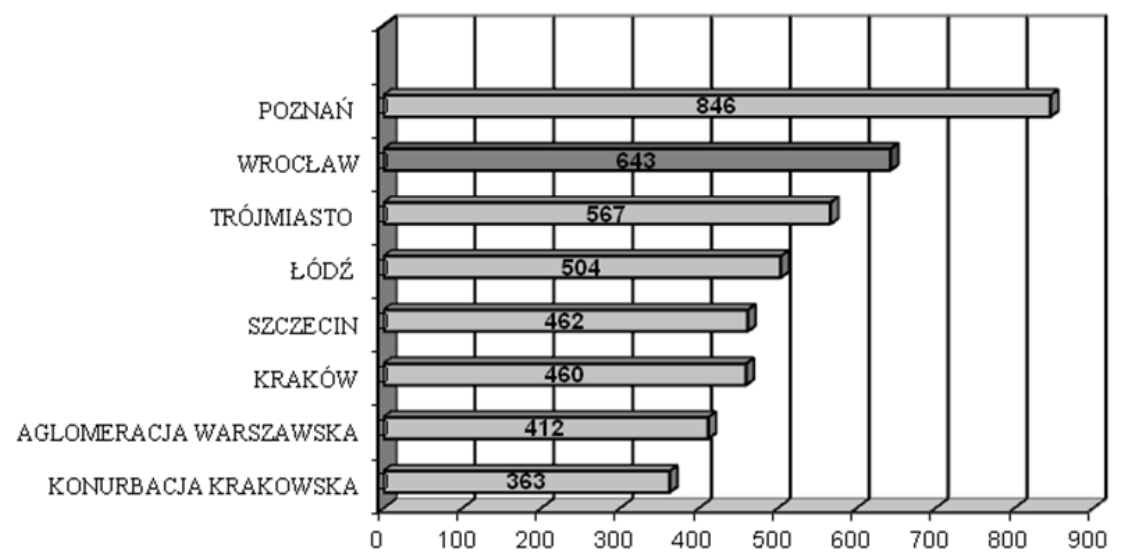

Fig. 2. Retail space saturation in $\mathrm{m}^{2}$ per 1,000 residents. Source: own elaboration using the Marketbeat Polish Real Estate Market Report, A Cushman \& Wakefield Research Publication (2013).

During the last five years covered by the analysis, i.e. 2005-2010, one might notice a significant boom in the supply of real estate area in Wrocław. This was especially apparent in the year 2007, which brought about a decrease in the creation of new retail space. As early as in 2010, supply for new retail space was no longer expected. Currently, with an increase in the number of vacant buildings, no rapid increase in available retail space is expected. However, shopping centers are being renovated and, occasionally, existing retail and recreational facilities are being added onto (Magnolia Park, the TESCO shopping arcade which is part of the Bielany Shopping Park, and Auchan, also part of Bielany). This fosters an increase in the quality of the space intended for rent, along with an increase in the attractiveness of the given place as quasi-public space.

The definite majority of the area within shopping centers in Wrocław, i.e. $88 \%$, is intended for use by the malls themselves, with the remaining space reserved for retail warehouses and wholesale centers (Fig. 3). It is clear to notice that the majority of the area in the segment of shopping centers is located within buildings where shopping arcades play a dominant role.

The offers of shopping centers and many marketing events are directed towards entire families. The Korona Shopping Center, one of the best-known malls in Wrocław, is one of the first multifunctional centers in Poland, where one can spend free time on activities other than shopping. Galeria Dominikańska also has a strong position on the Wrocław retail space market, being one of the oldest shopping centers in the country. Its favorable location, accessibility, close vicinity to the Old Town district and a rich assortment of lessees all undoubtedly help rank it among the most popular places for shopping and spending free time in the city. Galeria Dominikańska was opened in 2001 and renovated in 2011, attracting new lessees and a wider range of restaurants. Table 1 includes a set of basic information regarding the most important examples of retail space in Wrocław.

Magnolia Park is currently one of the largest shopping centers in the Lower Silesia region. Its location is convenient, as it stands near the busy exit road towards Zielona Gora. Many transportation routes lead to this shopping complex.

The popularity of shopping centers is also very high among residents of the region. People arrive at arcades and malls from towns located even over $60 \mathrm{~km}$ away (Kępno, Legnica, Wołów). Making this all the more convenient is the fact that shopping centers are situated near all of the main routes leading out of Wrocław:

- Magnolia Park Shopping Center - near the exit route towards Zielona Góra, 
- Korona Shopping Center and the Młyn Shopping Park-near the old exit route towards Warsaw,

- Bielany Shopping Park - near the Cracow-Zgorzelec highway link, one state road leading towards Kudowa Zdrój and another leading to Wałbrzych.

Additionally, the Marino Shopping Centre, not represented in Table 1, is located by the exit road towards Poznań.

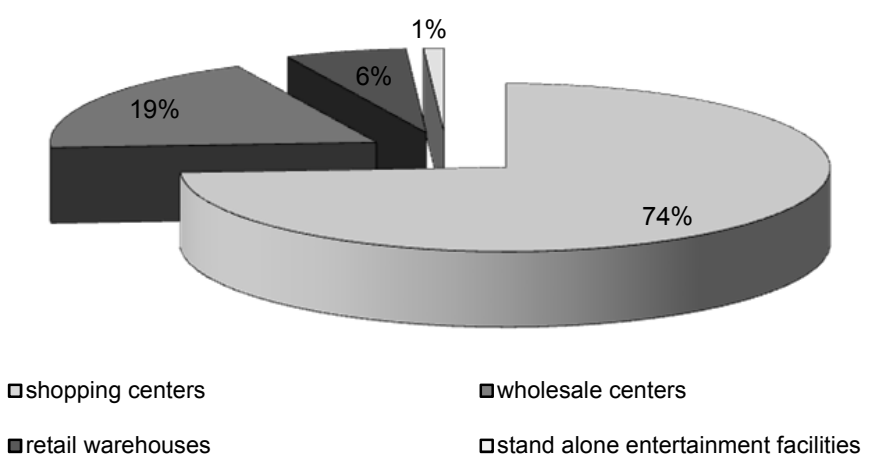

Fig. 3. Contemporary retail space supply. Source: own elaboration on the basis of Marketbeat Polish Real Estate Market Report, A Cushman \& Wakefield Research Publication, 2013.

Table 1

Basic information regarding the most important examples of retail space in Wrocław

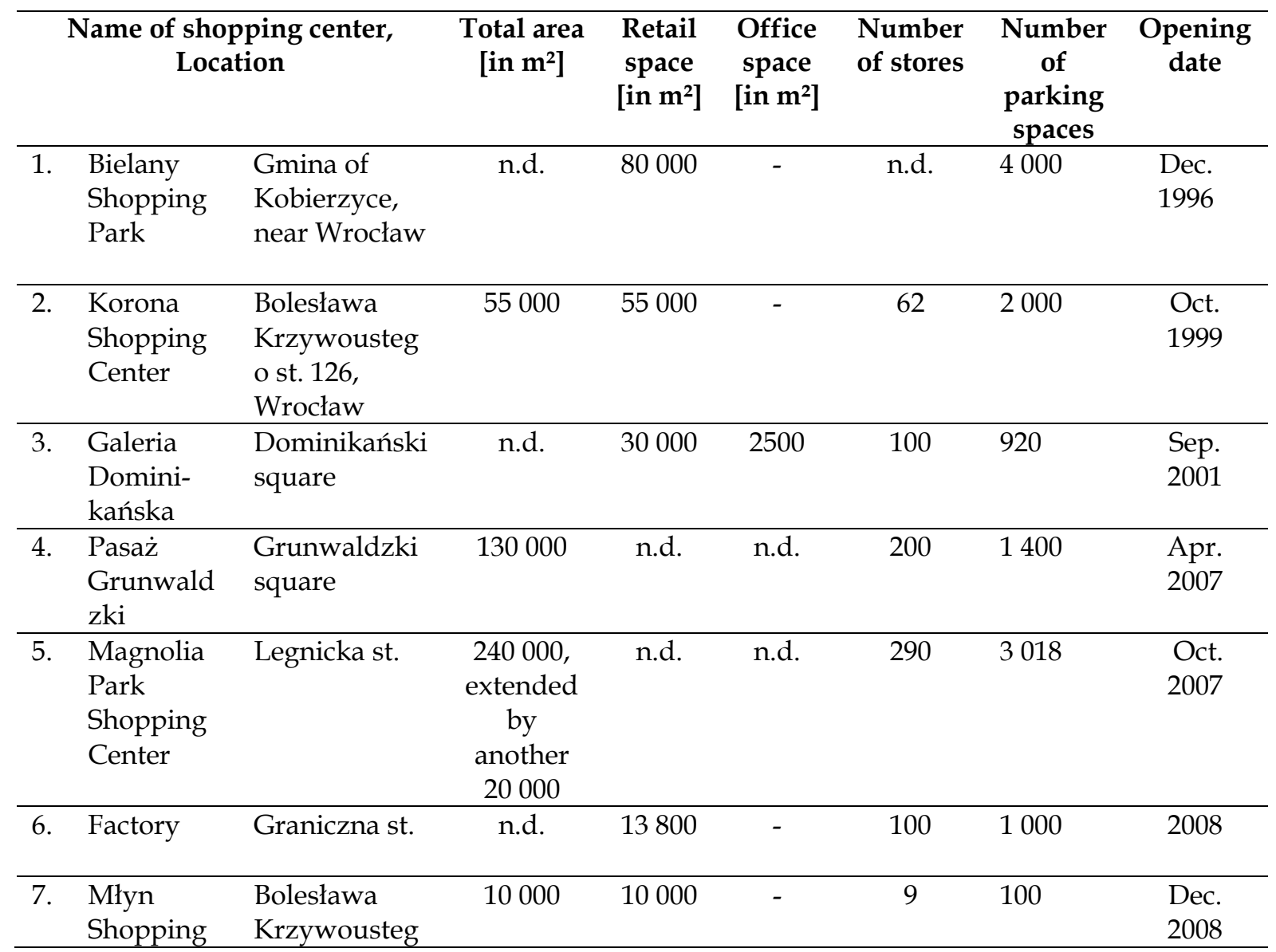




\begin{tabular}{llllllll}
\hline & Park & o st., Wrocław & & & & & \\
\hline 8. $\begin{array}{l}\text { Renoma } \\
\text { Mall }\end{array}$ & $\begin{array}{l}\text { Świdnicka st., } \\
\text { Wrocław }\end{array}$ & 99500 & 31000 & 10068 & 120 & 630 & $\begin{array}{c}\text { Apr. 2009 } \\
\text { located in } \\
\text { a former } \\
\text { retail } \\
\text { building } \\
\text { from 1930 }\end{array}$ \\
\hline 9. Sky Tower & $\begin{array}{l}\text { Powstańców } \\
\text { Śląskich } \\
\text { square }\end{array}$ & 28300 & 24000 & n.d. & n.d. & & $\begin{array}{c}\text { May } \\
2012\end{array}$ \\
& & & & & & & \\
\hline
\end{tabular}

n.d. - no data

Source: own elaboration.

\section{The impact of shopping centers on the environment}

A SWOT analysis was performed with the aim of the study in mind. Its results were later compared with observations made by students majoring in Geodesy and Cartography, as part of a course on real estate brokerage. A uniform point system from 0 to 2 was used to evaluate the impact of shopping centers operating in Wrocław. An evaluation of external threats related to the functioning of quasipublic space was especially important to the conducted study. In their assessment, the students indicated a series of dangers, including: unemployment growth and the creation of vacant structures in city centers due to an oversaturation of the market. These threats were awarded the highest amounts of points: 1.8 out of a maximum of 2 points. The consequences entailed by this sort of influence include a decrease in the attractiveness of a neighborhood deprived of trade services which had been taken over by shopping centers. The resulting decrease in attractiveness and decline in the value of real estate is a consequence of a lack of interest in investing. This problem was also noted by the students and attributed 1.6 points.

Shopping centers, as large-format and large-size structures, transform the landscape and panorama of cities. Quite often, as pointed out by CELIŃSKA-JANOWICZ (2011), this impact is negative, as it is the interior of these structures which is meant to attract users, hence their elevation very often takes on massive shapes with no though-out architectural form (HOPKINS 1991, JAŁOWIECKI, SZCZEPAŃSKI 2006, UNDERHILL 2005). Their presence in the landscape of a city very often leads to its degradation as opposed to its enhancement (KÜHN 2006).

The problem of small stores being displaced by shopping malls is also observable in Wrocław, for example in the area surrounding Grunwaldzki which ecompasses Pasaż Grunwaldzki, opened in the year 2007 (photos 1-4). Attractive locations of retail space on the ground floor of what were once modern students' residence halls and on the ground floors of tenement houses are currently nothing more than vacant structures.

On the other hand, shopping centers are perceived by the students as freely accessible places to meet and organize events. They do not see the limitations in their accessibility to certain people as a threat.

\section{Restrictions related to shopping center space}

Shopping centers delineate and create a new type of space which is closed and fully controlled. Taking this into account, one cannot entirely consider shopping centers as performing the functions of public space. Public space should not only be fully accessible, but also guarantee freedom of behavior, enable social contribution and provide conditions for interaction and diverse social activity (STAEHELI, MITCHELL 2006).

The users of shopping centers are, above all, consumers and their attention and activities should revolve mainly around consumption in its broad sense (in accordance with the economic interest of the owners of the malls and shops within them) (ZUKIN 1995). Retail structures utilize a number of limitations in order to ensure the safety of those within and the protection of property. These facilities are guarded by security personnel, who are to ensure safety within the building; additionally, these workers are to enforce regulations imposed by the owner or manager of the building. The work of the security personnel is made difficult due to the fact that most of the areas within shopping centers are accessible to everyone and because of the frequent changes among the staff. 
Specific information regarding the rules of use of retail structures should be located in a visible place, so that every customer can read it. Additionally, graphical signs indicating that certain actions are prohibited are placed throughout the center. One common restriction involves taking photographs. The manner of enforcing a no photographs restriction results from provisions regarding ownership rights (Article 140 of the Civil Code) and the scope of measures that can be taken to ensure their protection (Article $222 \S 2$ of the Civil Code). If a customer breaks the restriction regarding taking photographs imposed by the owner, the owner - or in this case people authorized by the owner - can demand him or her to stop taking photographs. This is confirmed by a judgment by the Supreme Court from January 30th, 2009, ref. no. II CSK 461/08, which states that ... the owner has the right to demand a third party which has breached his property to be forced to undertake a course of action leading to a change in the manner of using the real estate from one that is not in accordance with the owner's will to a different one, in accordance with the will of the owner and the law. This statement questions the public character of space enclosed within retail structures and bearing the markings of public space.

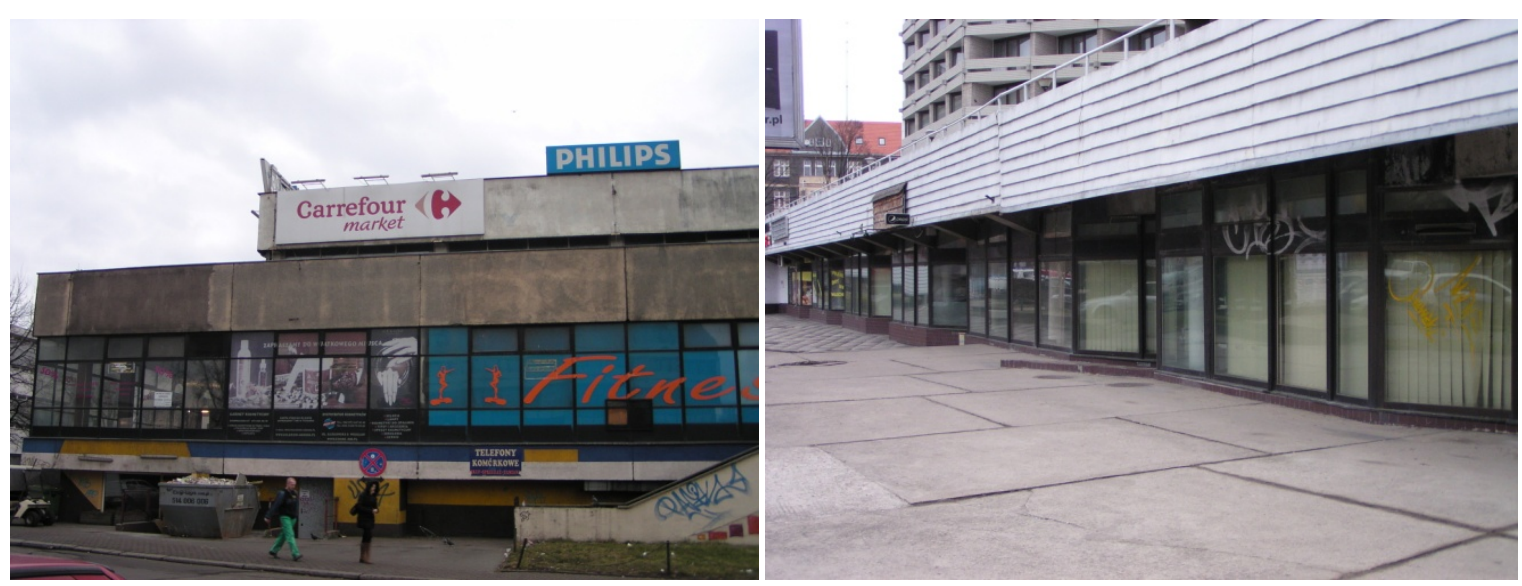

Photos 1 (left) and 2 (right). Former supermarket and shopping arcades on the ground floor of the Kredka and Ołówek students' residence halls, currently functioning as vacant structures located in the vicinity of the Grunwaldzki square in Wrocław. Author: Stacherzak A. 2014.
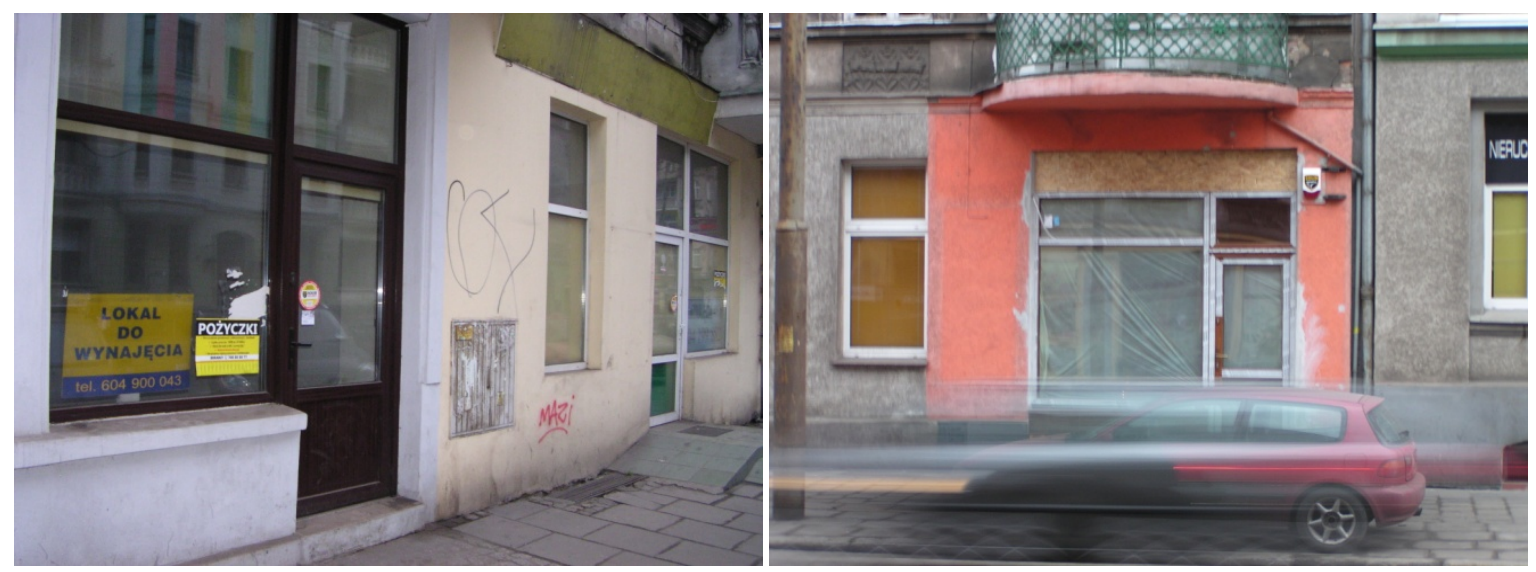

Photos 3 (left) and 4 (right). Retail space by Nowowiejska st. - currently vacant structures in the region of the Grunwaldzki square, Wrocław. Author: Stacherzak A. 2014.

\section{Conclusions}

Quasi-public space is not a type of ownership right distinguished by way of an act (GRAY 2010). It takes an intermediate position between a public zone and private one (HABDAS 2012; GRAY 2010). It is nominally private property, as it is granted to a private subject, yet functions as public property, since it fulfills the needs of more than one person.

Quasi-public space has entered city space for good as an effect of urban growth. Contemporary shopping centers are an attempt at substituting public space at a time when organized, user-friendly public space is lacking. 
On the other hand, one might be willing to agree with HABDAS (2012), who claims that deserted real estate classified as public property can hardly be considered public space, while privately owned real estate intended for public use is an example of a place that is private.

Shopping arcades in Wrocław fulfill the important function of a meeting place. One negative impact of this has to do with the accumulation of services which occurs within. This is beneficial with regard to the direct vicinity of the mall, yet brings losses to nearby streets, where it becomes unviable to provide commercial services or run other small business for local customers.

The interpretation of the law is unclear as regards the public nature of large-format retail facilities. Limited access to the inside and restrictions regarding certain actions which can usually be performed in public space make it difficult to define shopping malls as full-fledged public space.

\section{References}

CELIŃSKA-JANOWICZ D., 2011. Centra handlowe wobec miejskiej przestrzeni publicznej - nie tylko imitacja (Shopping Centers and Urban Public Space - Not Only an Imitation) [in:] Jażdżewska Iwona (red.): Konwersatorium Wiedzy o Mieście, Tom XXIV, Człowiek w przestrzeni publicznej miasta, Łódź: Wydawnictwo Uniwersytetu Łódzkiego, pp. 149-156.

CELKA K., 2012. Preferencje najemców na rynku nieruchomosci biurowych (Preferences of Lessees on the Commercial Real Estate Market). Studia i Materiały Towarzystwa Naukowego Nieruchomości, Vol. 20, No. 2, pp. 259-266, Olsztyn.

Collins D., Blomley N., 2003. Private Needs and Public Space: Politics, Poverty and Anti-Panhandling ByLaws in Canada, UBC Press, Vancouver-Toronto.

GLENNIE P., 1998, Consumption, Consumerism and Urban Form: Historical Perspectives, Urban Studies, 35(5-6), pp. 927-951.

GRAY K., 2010. Regulatory Property and the Jurisprudence of Quasi-Public Trust, Sydney Law Review, Vol. 32.

Habdas M., 2012. Publiczna wtasność nieruchomości (Public Ownership of Real Estate). LexisNexis, Warszawa

HopKINS J. S. P., 1991, West Edmonton Mall as a Centre for Social Interaction, The Canadian Geographer, No. 35(3), pp. 268-279.

JACKSON K. T., 1996, All the World's Mall: Reflections on the Social and Economic Consequences of the American Shopping Center, The American Historical Review, No. 101 (4), pp. 1111-1121.

JAŁOWIECKI B., SZCZEPAŃSKI M. S., 2006, Miasto i przestrzeń w perspektywie socjologicznej (The City and Space from the Sociological Perspective), Wyd. Naukowe Scholar, Warszawa.

KUCHARSKA - STASIAK E. 2006. Nieruchomość w gospodarce rynkowej (Real estate in the Market Economy). Wydawnictwo Naukowe PWN S.A. Warszawa

KÜHN G., 2006, Innerstädtische Einkaufszentren: Entwicklungen - Strukturen - Perspektiven, [in:] W. Brune, R. Junker, H. Pump-Uhlmann (ed.), Angriff auf die City, Droste Sachbuch, Düsseldorf, pp. 17-27.

LeHAVI A., 2008. Mixing Property. Seton Hall Law Review, Vol. 38:137, pp. 175-176.

MiciUKIEWICZ K., 2006, Pomiędzy strefa publiczna a przestrzenia publiczna w mieście, w: Strefa publiczna. Kondycja - przejawy - przemiany (Between the Public Zone and Public Space in the City, in: Public zone. Condition - expressions - changes). Lublin. Marketbeat Polish Real Estate Market Report, A Cushman \& Wakefield Research Publication, 2013

LASALLE J.L., 2012. Wrocławski rynek nieruchomości komercyjnych (Commercial Real Estate Market of Wroclaw). Invest in Wroclaw. Wroclaw Agglomeration Development Agency

PALICKI S., 2009. Karta przestrzeni publicznej jako instrument ksztattowania jakości przestrzeni miejskiej (Public Space Card as a Tool Shaping the Quality of Urban Space). Studia i Materiały Towarzystwa Naukowego Nieruchomości, Vol. 17, No. 3, pp. 103-112, Olsztyn.

POLKO A., 2006. Publiczny charakter nieruchomości (Public Nature of Real Estate). Nieruchomości No. 2 (2006), pp. 11-12.

Staeheli L. A., Mitchell D., 2006, USA's Destiny? Regulating Space and Creating Community in American Shopping Malls, "Urban Studies", No. 43 (5-6), pp. 977-992.

TARAJKO-BĄK A., 2001. Rynek powierzchni handlowych w Polsce (Commercial Space Real Estate Market in Poland).

TYNDAll A., 2010, It's a Public, I Reckon: Publicness and a Suburban Shopping Mall in Sydney's Southwest, Geographical Research, No. 48(2), pp. 123-136. 
UNDERHILL P., 2005, Call of the Mall. The Geography of Shopping, Simon \& Schuster Paperbacks, New York, London, Toronto, Sydney.

Ustawa o planowaniu i zagospodarowaniu przestrzennym z 27 marca 2003 r. (Act on Spatial Planning and Management of 27 March 2003) (tekst jednolity Dz. U. 2012, poz. 647 ze zm.).

Voyce M., 2006, Shopping malls in Australia: The End of Public Space and the Rise of "Consumerist Citizenship"? Journal of Sociology, No. 42(3), pp. 269-286.

Wyrok Sądu Najwyższego z dnia 30 stycznia 2009 r. (Judgement of the Supreme Court of 30 January 2009), sygn. akt II CSK 461/08 (file No. II CSK 461/08). 